\title{
SCIEnTific Article \\ Feasibility of the new method for orchid in vitro rooting using liquid and chemical sterilized culture medium under different sucrose concentration
}

\author{
Beatriz Cristina de Oliveira ${ }^{1}$, Maria Eduarda Barboza Souza de Oliveira ${ }^{1}$, Jean Carlos Cardoso ${ }^{2, *}$
}

\begin{abstract}
The in vitro propagation of orchids is the only commercial large scale technique to obtain healthy and high quality plantlets with clonal origin. The use of new technologies in plant tissue culture systems could lead to efficiency increases and costs reduction of micropropagation systems. The main actual micropropagation system is based on semi-solid culture media solidified using agar, followed by sterilization using autoclaving, and cultivation under photomixotrophic conditions using sucrose as main source of energy to plant in vitro culture. We proposed in this study the use of new micropropagation system using chemical sterilized liquid medium using polyurethane foam as support and LED source of light in rooting stage of Miltassia 'Shelobie Tolkien'. Thus, the objective of this research was to test different concentrations of sucrose, comparing the conventional semi-solid agar-based culture medium (control) and the use of liquid medium with polyurethane foam support. The following sucrose concentrations were used: $0,7.5,15,22.5$ and $30 \mathrm{~g} \mathrm{~L}^{-1}$. The experiment was conducted in a 2 x 5 factorial, in a completely randomized design with ten replications each over a total period of 105 days of cultivation. The chemical sterilization using $\mathrm{ClO}_{2}$ showed $100 \%$ of decontamination in all treatments. The use of liquid media with polyurethane foam showed better results than plants cultivated in agar medium, and can be used for replace agar-based for orchid in vitro rooting.
\end{abstract}

Keywords: Agar, polyurethane foam, micropropagation system, plantlet development, chlorine dioxide

\section{Resumo}

Viabilidade do novo método para o enraizamento in vitro de orquídeas utilizando meio de cultura líquido e esterilizado quimicamente sob diferentes concentrações de sacarose

A propagação in vitro de orquídeas é a única técnica comercial em larga escala para obtenção de plântulas saudáveis e de alta qualidade com origem clonal. O uso de novas tecnologias em sistemas de cultura de tecidos vegetais pode levar a aumentos de eficiência e redução de custos dos sistemas de micropropagação. O principal sistema de micropropagação atual é baseado em meios de cultura semi-sólidos solidificados usando ágar, seguido de esterilização pela autoclavagem, e cultivo sob condições fotomixotróficas usando sacarose como principal fonte de energia para o cultivo in vitro de plantas. Neste estudo foi proposto o uso de um novo sistema de micropropagação utilizando meio líquido esterilizado quimicamente e utilizando espuma de poliuretano como suporte e fonte de luz LED para ocultivo in vitrode Miltassia 'Shelobie Tolkien'. O objetivo desta pesquisa foi testar diferentes concentrações de sacarose, comparando o meio de cultura convencional semissólido à base de ágar (controle) e o uso de meio líquido com suporte de espuma de poliuretano. Foram utilizadas as seguintes concentrações de sacarose: 0, 7,5, 15, 22,5 e 30 $\mathrm{g} \mathrm{L}^{-1}$. O experimento foi conduzido em fatorial 2 x 5, com delineamento inteiramente casualizado, somando um total de 105 dias de cultivo. A esterilização química com o $\mathrm{ClO}_{2}$ mostrou $100 \%$ de descontaminação em todos os tratamentos. O uso de meios líquidos com espuma de poliuretano apresentou melhores resultados do que plantas cultivadas em meio semi-solidificado com ágar, e pode ser utilizado para substituir os atuais sistemas de cultivo in vitro baseados em ágar.

Palavras-chave: Agar, espuma de poliuretano, sistema de micropropagação, desenvolvimento da plântula, dióxido de cloro

\footnotetext{
${ }^{1}$ Universidade Federal de São Carlos, Centro de Ciências Agrárias, Araras-SP, Brazil.

${ }^{2}$ Universidade Federal de São Carlos, Centro de Ciências Agrárias, Departamento de Biotecnologia e Produção Vegetal e Animal, Araras-SP, Brazil.

*Corresponding author: jeancardoso@ufscar.br
} 


\section{Introduction}

The Orchidaceae family represents about 25,000 species, as well as thousands of hybrids around the world, being the largest family among monocotyledons (Zahara et al., 2017). The most economic value of orchids is attributed to the ornamental value due to the beauty, diversity of colors and forms of its flowers, but some orchids were used as medicinal plant, as example in traditional Chinese medicine (Silva et al., 2016).

The commercial production of ornamental orchids utilizes for propagation asymbiotic in vitro germination and cloning techniques of plants as the only techniques with commercial feasibility to obtain healthy and high quality plantlets in a large scale production. This technique was also applied in the production of species that are environmentally vulnerable or endangered (Datta et al. 2017; Faveta et al., 2017).

The Murashige and Skoog (1962) medium (MS) is the most used for the in vitro propagation of orchids, and depending of the species or hybrid used for micropropagation, the macronutrient concentrations of the medium are modified, reduced by half $(1 / 2 \mathrm{MS})$ to meet the plant requirements necessary for in vitro development of plantlets (Silva et al. 2015). These modifications resulted in better development of micropropagated plantlets, but in most of the experiments these modifications are limited to nutrients, including treatments with types and concentrations of plant growth regulators, such as cytokinins and auxins (Park and Yeung, 2017).

The use of $1 / 2 \mathrm{MS}$ semi-solid agar-based containing sucrose at $2 \%-3 \%$ into the culture medium and white fluorescent-bulbs as source of light, under photomixotrophic conditions, is the most system used for orchid micropropagation (Silva et al. 2015). Both the agar and the sucrose influence the in vitro development of species, with direct correlation between the higher degree of purity and increase of cost of these products (Daud et al., 2011), which increase costs of micropropagated plantlets.

The sucrose is the main source of carbohydrates in the culture medium and energetically supports the development of shoots and plantlets cultivated in vitro, main because photosynthesis is limited on these conditions by the reduced gas exchange between in vitro and ex vitro environment and low light intensity used in growth rooms for maintain the plantlets development. Although sucrose is essential in conventional micropropagation, concentration studies help to improve its use (Zahara et al., 2017) and experiments are required, especially for the development of new systems for in vitro cultivation aiming the reduction of it use, or even avoid it use in culture medium (sucrose-free media) for micropropagation to promote a realistic way for the photoautotrophic micropropagation.

The search and use of new disposable technologies that replace conventional photomixotrophic micropropagation methods could be used aiming to increase the efficiency and to reduce costs of micropropagated plantlets, one of the most challenges in this century. Studies realized by Grzegorczyk-Karolak et al. (2016) show that the liquid culture medium combined with the polyurethane foam as support, improved plantlets performance in vitro and it can be a new alternative to replace agar in vitro cultivation of plantlets. In addition, new technologies for lighting, as lighting-emitting diode (LEDs) showed an excellent alternative to replace actual white cold fluorescent lighting (Bello-Bello et al., 2017).

Similarly, chemical sterilization of culture media using chlorine dioxide $\left(\mathrm{ClO}_{2}\right)$ proved be highly efficient for replace autoclaving and has been successfully used in in vitro cultivation of ornamental plants such as anthurium (Cardoso, 2009) and gerbera (Cardoso and Imthurn, 2018), without phytotoxicity effects under effective concentrations. Among the advantages of chemical sterilization using $\mathrm{ClO}_{2}$ is the efficient decontamination with non-phytotoxicity effects. In addition, compared to autoclaving, allow the use of new materials and chemicals that are thermolabile and that resulted in phytotoxicity substances release in culture medium caused by high temperatures treatment, such as sucrose (Brondani et al., 2013; Cardoso and Imthurn, 2018; Gavilan et al., 2018).

Based on these previous studies, the objectives were to test a new method using chemical sterilized and liquid medium with polyurethane foam as support for plantlet development, to replace agar-based conventional medium in orchids, under five different concentrations of sucrose.

\section{Material and Methods}

For the experiment there was used the commercial hybrid Miltassia 'Shelobie Tolkien', which has as characteristics fast and vigorous growth, early flowering compared with other related hybrids, and starlit flowers with brown color of petals and sepals, with rose lip. All the shoots used in the experiment originated from multiplication phase of in vitro micropropagation, obtained from shoot-tip culture, therefore of clonal origin and obtained from a protocol developed in the Laboratory of Plant Physiology and Tissue Culture (LFVCT) of the Center of Agricultural Sciences of Federal University of São Carlos (UFSCar).

The experiment was conducted at rooting stage of orchid micropropagation. There were used test tubes which were initially washed with running tap water and neutral detergent prior to use. The culture medium used was Murashige and Skoog (1962) with half of the concentration of macronutrients $(1 / 2 \mathrm{MS})$, with addition of $0.1 \mathrm{~g} \mathrm{~L}^{-1}$ inositol and without the application of plant growth regulators, established according previous protocols developed and used for the rooting and elongation of the plantlets in the LFVCT-UFSCar.

The experiment tested the physical state of the culture medium and the sucrose concentrations. The semi-solid culture medium was obtained by addition of $6.5 \mathrm{~g} \mathrm{~L}^{-1}$ agar and the liquid medium was supported by polyurethane foam (PoF) (Agriespuma ${ }^{\circledR}$, Ibiúna, Brazil). Both media were supplemented with different concentrations of sucrose, being: $0,7.5,15,22.5$ and $30 \mathrm{~g} \mathrm{~L}^{-1}$.

The experiment were conducted under new disposable technologies, e.g. chemical sterilization of culture media 
with $\mathrm{ClO}_{2}$, instead of conventional autoclaving, and the use of LED lighting source with blue/red wavelengths $(1: 2)$ to replace white cold-fluorescent tubes conventionally used for in vitro orchid micropropagation.

The culture media were chemically sterilized using the protocol developed by Cardoso (2009), using the active chlorine concentration of $0.0035 \%$ and the commercial product Dioxiplus ${ }^{\circledR}$ (Indaiatuba, Brazil) with active ingredient chlorine dioxide $\left(\mathrm{ClO}_{2}\right)$. After addition of $\mathrm{ClO}_{2}$ (chemical sterilization), the $\mathrm{pH}$ of the culture medium was adjusted to 6.2 prior to the addition of the Agar or the polyurethane foam and dispensed into the culture test tubes. To each test tube was added $12 \mathrm{ml}$ of culture medium. A total of 10 test tubes containing one shoot each (replicate) per treatment were used. A transparent polypropylene plastic cap was used for cover test tubes.

The experiment was conducted in factorial 5 (sucrose concentrations) $\times 2$ (semi-solid or liquid $+\mathrm{PoF}$ ), in a completely randomized design with ten replicates for each treatment.

For the evaluations of in vitro plantlet growth, there were measured biweekly the plant height and the leaf number, over a total period of 105 days of cultivation. At the end of the cultivation period, the longest root and the fresh weight for each plantlet were also measured.

The acclimatization was carried out by washing the roots with tap water and then planted in plastic trays of 200 cells containing commercial substrate Carolina Soil ${ }^{\circledR}$ (Pardinho, Brazil) based on peat, vermiculite and charred rice husk. The plantlets were transferred to greenhouse covered with agricultural plastic diffuser and aluminum color shading cover ( $65 \%$ shading capacity), irrigated daily with approximately $1 \mathrm{~mm}$ of water and weekly fertigated with commercial solution of fertilizers (Plant-Prod $\AA$, 2020-20 + micronutrients) and electrical conductivity of 1.0. The survival of the plants was quantified at 90 days of cultivation under greenhouse conditions and presented in percentage of survival plantlets.

The data obtained at 105 days of cultivation were deducted of data zero to evaluate the increases of variables among the period of cultivation. The results obtained were submitted to Analysis of Variance, followed by the use of means comparison Scott-Knott test at $\mathrm{P}=0.01$ and 0.05 . The data of number of leaves was also submitted to analysis of regression.

\section{Results and Discussion}

Chemical sterilization with $\mathrm{ClO}_{2}$ demonstrated high efficiency for sterilization of the culture media, independently of the sucrose concentration and if used agar-based or liquid media with polyurethane foam (PoF). During 105 days of in vitro cultivation, none of visible contamination in the culture medium was observed. The successfully sterilization of the culture medium was already reported for other species and showed the high efficiency of the $\mathrm{ClO}_{2}$ to effectively perform the sterilization of the culture medium, without causing phytotoxicity effects to different commercial ornamental plants grown in vitro (Cardoso and Imthurn, 2018). This is the first report of the use of $\mathrm{ClO}_{2}$ for successful chemical sterilization of culture media in orchid cultivation using liquid media.

Similarly, the use of LED-lighting with blue/ red wavelengths were considered satisfactory for the micropropagation of Miltassia 'Shelobie Tolkien', with plantlets morphologically similar to those developed under conventional white-fluorescent light (data not showed). The use of LEDs has as advantages compared with fluorescent lights, because the last one produces wide range of wave lengths not required by development of micropropagated plants, while red-blue LED concentrated more useful wave lengths. The use of blue-red LEDs also has effects on orchid development, increasing chlorophyll contents $(\mathrm{a}, \mathrm{b}$ and $\mathrm{a}+\mathrm{b})$ and showing similar development of in vitro plantlets of Phalaenopsis orchids, compared to those cultivated with conventional fluorescent white light (Bello-Bello et al. 2017).

The development of Miltassia 'Shelobie Tolkien' orchid plants was possible and considered highly satisfactory in both culture media, solidified with Agar, or in liquid medium containing the polyurethane foam $(\mathrm{PoF})$ as support (Table 1). 
Table 1. In vitro development of Miltassia 'Shelobie Tolkien' in culture medium containing different sucrose concentrations, chemically sterilized and semi-solid or liquid + Polyurethane foam (PoF) support

\begin{tabular}{|c|c|c|c|c|c|c|c|}
\hline \multirow{2}{*}{\multicolumn{2}{|c|}{$\begin{array}{c}\text { Miltassia } \\
\text { 'Shelobie Tolkien' }\end{array}$}} & \multicolumn{6}{|c|}{ Sucrose concentration $\left(\mathrm{g} \mathrm{L}^{-1}\right)$} \\
\hline & & \multirow{2}{*}{$\begin{array}{c}\mathbf{0 . 0} \\
1.65\end{array}$} & \multirow{2}{*}{$\begin{array}{c}7.5 \\
0.37\end{array}$} & \multirow{2}{*}{$\begin{array}{l}\mathbf{1 5 . 0} \\
1.32\end{array}$} & \multirow{2}{*}{$\begin{array}{l}\mathbf{2 2 . 5} \\
1.82\end{array}$} & \multirow{2}{*}{$\begin{array}{l}\mathbf{3 0 . 0} \\
1.49\end{array}$} & \multirow[t]{2}{*}{ Mean } \\
\hline Gains in shoot & Agar & & & & & & \\
\hline Height (cm) & PoF & 1.33 & 1.25 & 1.32 & 0.98 & 0.80 & \\
\hline \multirow{3}{*}{$\begin{array}{c}\text { Gains of number } \\
\text { of leaves }\end{array}$} & Agar & 3.8 & 8.7 & 7 & 8.2 & 8.2 & \\
\hline & PoF & 4.2 & 6.1 & 7.6 & 6 & 7.9 & \\
\hline & Mean & $4.0 \mathrm{~b}$ & $7.4 \mathrm{a}$ & $7.3 \mathrm{a}$ & $7.1 \mathrm{a}$ & $8.1 \mathrm{a}$ & \\
\hline \multirow{2}{*}{$\begin{array}{c}\text { Gains in longest } \\
\operatorname{root}(\mathrm{cm})\end{array}$} & Agar & 0.82 & 0.84 & 1,04 & 0.8 & 1.05 & \\
\hline & PoF & 0.55 & 0.72 & 1.11 & 1.18 & 0.99 & \\
\hline \multirow{4}{*}{$\begin{array}{l}\text { Fresh weight } \\
\text { (g/plant) }\end{array}$} & Agar & 0.175 & 0.298 & 0.333 & 0.234 & 0.405 & $0.289 \mathrm{~b}$ \\
\hline & PoF & 0.236 & 0.484 & 0.594 & 0.744 & 0.719 & $0.555 \mathrm{a}$ \\
\hline & Mean & $0.206 \mathrm{~b}$ & $0.391 \mathrm{a}$ & $0.464 \mathrm{a}$ & $0.489 \mathrm{a}$ & $0.562 \mathrm{a}$ & \\
\hline & Shoot height & Longest root & Number of leaves & Fresh weight & & & \\
\hline Agar/PoF & $0.95 \mathrm{~ns}$ & $0.01 \mathrm{~ns}$ & $2.00 \mathrm{~ns}$ & $24.04 * *$ & & & \\
\hline Sucrose & $1.42 \mathrm{~ns}$ & $0.90 \mathrm{~ns}$ & $2.51 *$ & $6.77 * *$ & & & \\
\hline Agar/PoF x Sucr & $1.89 \mathrm{~ns}$ & $0.43 \mathrm{~ns}$ & $0.55 \mathrm{~ns}$ & $1.99 \mathrm{~ns}$ & & & \\
\hline CV $(\%)$ & 25.32 & 20.89 & 33.91 & 8.44 & & & \\
\hline Transformation & $\sqrt{x}+1$ & $\sqrt{x}+1$ & $\sqrt{x}+1$ & $\sqrt{x}+1$ & & & \\
\hline
\end{tabular}

${ }^{1}$ Means followed by the same letters do not differ from each other by the Scott \& Knott means test at $5 \%(*)$ or $1 \%(* *)$ probability.

No significant differences were observed for the sucrose and cultivation system factors for the variables analyzed plant height and length of the longest root. Sucrose concentrations had effect in the number of leaves/plantlets and the fresh weight of plantlets was the only variable that was influenced by both factors tested.

The use of the polyurethane foam $(\mathrm{PoF})$ was resulted in significant gains in the fresh weight compared to the use of the conventional medium semi-solidified with Agar. The use of PoF resulted in an average increase of $92 \%$ in the fresh weight when compared to the plantlets obtained in agar medium. The highest increase (218\%) was observed in the sucrose concentration of $22.5 \mathrm{~g} \mathrm{~L}^{-1}$. Also in sucrosefree medium there were observed increases of 35\% in fresh weight using PoF, compared with agar, showing a better performance of plantlets since in sucrose-free media.

The fresh weight of plantlets differed when compared the free-sucrose medium $\left(0 \mathrm{~g} \mathrm{~L}^{-1}\right)$ with the sucrose-added medium, regardless of the concentration used (7.5 to $30 \mathrm{~g}$ $\mathrm{L}^{-1}$ ). This same result was observed for the number of leaves per plantlet, demonstrating that the presence of sucrose, even at low concentrations $\left(7.5 \mathrm{~g} \mathrm{~L}^{-1}\right)$ resulted in increases in the fresh weight gain and better vegetative development of the plantlets than those grown in the absence of sucrose, confirming the photomixotrophic development.

The importance of sucrose to in vitro plant cultivation is conceptually known, including many reports on its use and benefits for orchid in vitro cultivation. As example, in Oncidium baueri there was observed that the use of the $1 \frac{1}{2} \mathrm{MS}$ culture medium associated with sucrose concentration of 40 $\mathrm{g} \mathrm{L}^{-1}$ showed increases in shoot height $(63 \%)$, root number $(64.1 \%)$ and the total fresh weight (106\%), when compared to the control medium containing $30 \mathrm{~g} \mathrm{~L}^{-1}$ sucrose (Sorace et al., 2008). However, the concentration of sucrose appears to be genotype-dependent, and for Cattleya loddigesii, the use of sucrose concentrations greater than $20 \mathrm{~g} \mathrm{~L}^{-1}$ did not result in benefits for in vitro development and survival of the seedlings in ex vitro acclimatization conditions (Galdiano Júnior et al., 2013).

In spite of these differences observed for other orchid species, the observations realized in actual study using cloned plantlets of Miltassia 'Shelobie Tolkien', showed that the only differences were observed between the absence and presence of sucrose in the culture medium, regardless of the concentration used. Although sucrose shows benefits for the in vitro plantlet development, it has been demonstrated that their presence in the culture medium can results in important physiological abnormalities, such as the excessive opened stomata and difficulties for the establishment of stomata control to reduce excessive transpiration in plantlets cultivated in vitro in pre-acclimatization stage (Cardoso et al., 2013). In this previous study with gerberas, the combination of greenhouse conditions (natural sunlight) associated 
with the absence of sucrose in the culture medium may result in better acclimatization of the plantlets, favoring the acquisition of photoautotrophy even when the in vitro plantlets showed limited in vitro development under free-sucrose medium (Cardoso et al., 2013). This was also observed in actual study with Miltassia orchid, in which the plantlets grown in the absence of sucrose could be acclimatized and presenting similar morphology and development to those grown in medium containing sucrose, showing that plantlets cultivated in vitro in the absence of sucrose could be better response to acclimatization conditions. The success of acclimatization was high, with approximately $90 \%$ of plantlet survival in all treatments, including sucrose-free media.

Another important fact observed in this study was the greater increase of the fresh weight using the liquid medium + PoF, in comparison to the medium solidified with agar. The increase in fresh weight was the result of the increase in other observed, but not evaluated items, such as the larger leaf diameter and pseudobulbs in the plantlets of Miltassia 'Shelobie Tolkien' cultivated in vitro, visibly increasing the quality of the plantlets obtained using this culture system (Figure 1).
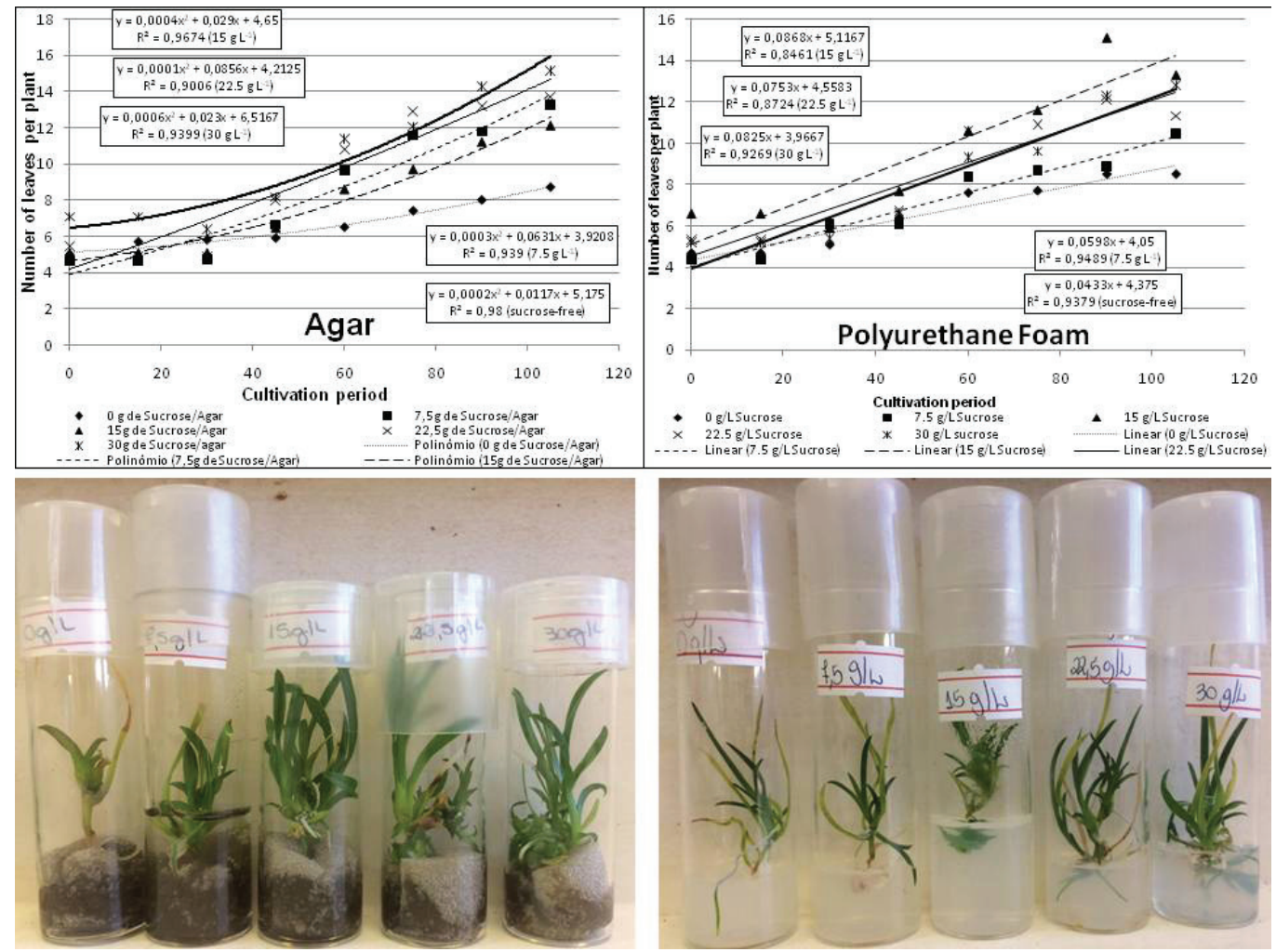

Figure 1. Number of new leaves developed in in vitro cultivation period and in vitro morphology of Miltassia 'Shelobie Tolkien' in culture medium containing different sucrose concentrations with Polyurethane foam (PoF) support compared to agar-medium

The use of liquid medium may bring benefits to in vitro plant micropropagation, such as increased available and uptake of nutrients through the culture medium, but also can lead to non-desirable responses when cultivated under anaerobic conditions (undersolution), with negative consequences to the development of in vitro plantlets. In this sense, the use of temporary immersion bioreactors (TIB) (Zhang et al., 2018) or supports combined with the stationary liquid medium are alternatives to avoid the problem of anaerobiosis on in vitro plant tissue culture. Among the few works using PoF as a support for in vitro cultivation, GrzegorczykKarolak et al. (2016) found that the use of stationary liquid medium in combination with the use of PoFbased support resulted in the greatest increase of fresh and dry weight in Scutellaria alpina plantlets cultured in vitro, when compared to the conventional medium semisolidified with agar.

One of the differences observed in actual study with using Miltassia 'Shelobie Tolkien' orchid was that the resumption of the plantlets development, after the transference to the new culture medium, was faster and linear in the liquid medium with PoF compared to agar medium (Figure 1). An example could be visualized with the number of leaves, in which the use of liquid medium resulted in linear correlation between development of the new leaves and cultivation period, whereas in medium containing agar there was observed a long period of adaptation (first 40-50 days of cultivation) of the plantlets to the new and nutrient-rich culture medium, followed by the resumption of the production of new leaves only after this period (Figure 1A). 


\section{Conclusions}

The combination of chemical sterilization using $\mathrm{ClO}_{2}$, plantlets cultivation in blue/red LEDs with higher energyefficiency and the use of liquid medium using polyurethane foam as a support provided favorable conditions for the in vitro development of plants, proving their efficiency for orchid micropropagation, with benefits also in the next acclimatization phase. These new technologies are an important tool for the advances in the in vitro micropropagation of plantlets, especially to obtain more efficient systems, with lower cost and also aiming the photoautotrophic micropropagation.

\section{Author Contribution}

As individual contributions of the authors, B.C.O. ${ }^{0000-0003-}$ ${ }^{2828-2524}$ and M.E.B.S.O. ORCID, ${ }^{0000-0002-5683-7067}$ contributed to the installation and evaluation of the experiment, statistical analysis and writing of the scientific article. J.C.C. ${ }^{0000-0001-6578-1723}$ contributes to the conceptualization of the experiment, experimental design, writing and interpretation of results and final revision of the scientific article.

\section{Acknowledgements}

JCC acknowledges CNPQ for the Process 304174/2015-7 and 311083/2018-8. JCC and MEBSO thanks to Sao Paulo Research Foundation for the fellowship to MEBSO, Process number 2019/00243-7.

\section{References}

BELLO-BELLO, J.J.; PÉREZ-SATO, J.A.; CRUZCRUZ, C.A.; MARTÍNEZ-ESTRADA E. Light-Emitting Diodes: Progress in Plant Micropropagation. pp.93-103, Intechopen. 2017. DOI:105772/67913.

BRONDANI, G.E.; OLIVEIRA, L.S.; BERGONCI, T.; BRONDANI, A.E.; FRANÇA, F.A.M.; SILVA, A.L.L.; GONÇALVES, A.N. Chemical sterilization of culture medium: a low cost alternative to in vitro establishment of plants. Scientia Forestalis, v.98, n.41, p.257-264, 2013.

CARDOSO, J.C. Esterilização química de meio de cultura no cultivo in vitro de antúrio. Pesquisa Agropecuária Brasileira, v.44, n.7, p.785-788, 2009. http://dx.doi. org/10.1590/S0100-204X2009000700020.

CARDOSO, J.C.; INTHURN, A.C.P. Easy and efficient chemical sterilization of the culture medium for in vitro growth of gerbera using chlorine dioxide $\left(\mathrm{ClO}_{2}\right)$. Ornamental Horticulture, v.24, n.3, p.218-224, 2018. http://dx.doi.org/10.14295/oh.v24i3.1222.
CARDOSO, J.C.; ROSSI, M.L.; ROSALEM, I.B.; SILVA, J.A.T; Pre-acclimatization in the greenhouse: alternative to optimizing the micropropagation of gerbera. Scientia Horticulturae, v.164, p.616-624, 2013. https://doi. org/10.1016/j.scienta.2013.10.022

DATTA, S.K.; CHAKRABORTY, D; JANAKIRAM, T. Low cost tissue culture: an overview. Journal of Applied Sciences Research, v.2, n.33, p.181-199, 2017.

DAUD, N.; TAHA, R.M.; NOOR, N.N.M.; ALIMON, H. Potential of Alternative Gelling Agents in Media for the in vitro Micro-propagation of Celosia sp. International Journal of Botany, v.7, n.2, p.183-188, 2011. http://dx.doi. org/10.3923/ijb.2011.183.188.

FAVETTA, V.; COLOMBO, R.C.; MANGILI JÚNIOR, J.F.; FARIA, R.T. Light sources and culture media in the in vitro growth of the Brazilian orchid Microlaelia lundii. Semina: Ciências Agrárias, v.4, n.38, p.1775-1785, 2017. http://dx.doi.org/10.5433/1679-0359.2017v38n4p1775

GALDIANO JUNIOR, R.F.; MANTOVANI, C.; FARIA, R.T.; MACEDO LEMOS, E.G. Concentrações de sacarose no desenvolvimento in vitro e na aclimatização de Cattleya loddigesii Lindley. Semina: Ciências Agrárias, v.34, n.2, p.583-592, 2013. http://dx.doi.org/10.5433/16790359.2013v34n2p583.

GAVILAN, N.H.; FURLAN, F.C.; ZORZ, A.Z.; OLIVEIRA, L.S.; CAMPOS, WF, BRONDANI, G.E. Chemical sterilization of culture medium for in vitro multiplication of Cochlospermum regium. Ciência Rural, v.48, n.9, p.1-7, 2018. http://dx.doi.org/10.1590/0103$8478 \mathrm{cr} 20170581$.

GRZEGORCZYK-KAROLAK, I.; RYTCZAK, P.; BIELECKI, S.; WYSOKINSKA, H. The influence of liquid systems for shoot multiplication, secondary metabolite production and plant regeneration of Scutellaria alpina. Plant Cell, Tissue and Organ Culture, v.128, n.2, p.479486, 2016. http://dx.doi.org/10.1007/s11240-016-1126-y.

MURASHIGE, T.; SKOOG, F. A revised medium for rapid growth and biossays with tobacco tissue cultures. Physiologya Plantarum, v.15, p.473-497, 1962. https:// doi.org/10.1111/j.1399-3054.1962.tb08052.x

PARK J.; YEUNG E.C. Orchid Seed Germination and Micropropagation II: Media Information and Composition. In: LEE YI., YEUNG ET. (eds) Orchid Propagation: From Laboratories to Greenhouses Methods and Protocols. Springer Protocols Handbooks. Humana Press, New York, NY, p.127-150, 2018. https:// doi.org/10.1007/978-1-4939-7771-0_6 
SORACE, M; FARIA, R.T.; DAMASCENO JÚNIOR, C.V.; GOMES, G.P.; BARBOSA, C.M.; VIEIRA; F.G.N; SILVA, G.L.; TAKAHASHI, L.S.A; SCHNITZER, J.A. Crescimento in vitro de Oncidium baueri (Orchidaceae) em diferentes concentrações de macronutrientes e sacarose. Semina: Ciências Agrárias, v.29, n.4, p.775-782, 2008. http://dx.doi.org/10.5433/1679-0359.2008v29n4p775

SILVA, J.A.T.; CARDOSO, J.C.; DOBRÁNSZKI, J.; ZENG, S. Dendrobium micropropagation: a review. Plant Cell Reports, v.34, n.5, p.671-704, 2015. https://doi. org/10.1007/s00299-015-1754-4
SILVA, J.A.; JIN, X.; DOBRÁNSZKI, J.; LU, J.; WANG, H.; ZOTZ, G.; CARDOSO, J.C.; ZENG, S. Advances in Dendrobium molecular research: Applications in genetic variation, identification and breeding. Molecular Phylogenetics and Evolution, v.95, p.196-216, 2016. https://doi.org/10.1016/j.ympev.2015.10.012

ZHANG, B.; SONG, L.; BEKELE, L.D.; SHI, J.; JIA, Q.; ZHANG, B.; JIN, L.; DUNS, G.J.; CHEN, J. Optimizing factors affecting development and propagation of Bletilla striata in a temporary immersion bioreactor system. Scientia Horticulturae, v.232, p.121-126, 2018. https:// doi.org/10.1016/j.scienta.2018.01.007 